\title{
OBSERVACIONES EN CHICHICASTENANGO EN 1969
}

por Ruth GRUHN, University of Alberta

Con objeto de obtener experiencia personal en una comunidad indígena de la América media, la autora residió dos meses en Santo Tomás Chichicastenango, un municipio de las tierras altas de Guatemala de cerca de 40000 habitantes indígenas hablantes de quiché, lugar bien conocido de los antropólogos debido al estudio de Ruth Bunzel de hace casi 40 años (Bunzel, 1952). El periodo en cuestión transcurrió del 9 de octubre al 11 de diciembre de 1969. Ya que me he especializado básicamente en arqueología y no en antropología social, no intentaré aquí presentar una nueva interpretación teórica; este artículo pretende añadir información derivada de un trabajo de campo que suministre al lector interesado alguna descripción etnográfica adicional para completar la monografía de Bunzel e indicar cambios recientes dentro de la comunidad, así como sugerir asuntos importantes a tratar en la investigación futura.

Una cualidad notable de un estudio antropológico es la forma en que prepara a un profano para compenetrarse con la cultura descrita, y en este sentido la monografía de Bunzel cumple óptimamente. La cultura maxeña * es muy compleja en su estructura y dinámica, y la detallada descripción de Bunzel acerca de su organización y los diversos acontecimientos relacionados con ella me permitieron conocer con precisión desde el principio la estructura básica de la comunidad y el sentido de las diversas actividades observadas. Mi admiración por la capacidad de Bunzel al registrar los hechos crecía a medida que me compenetraba por mí misma más y más con los detalles de la cultura.

Bunzel se apoyó principalmente en un informante para recoger información: "Manuel" (que murió en 1966); y realmente fue afortunada al escogerlo, debido a que este hombre, por su status social y

Traducción de Javier Guerrero.

- Max es la forma quicheizada de Tomás, Santo patrono de Chichicastenango. 
religioso, conocía casi todos los aspectos de la cultura. Yo no tuve tanta suerte, pero me pareció bien el auxilio de Sebastián, un inválido muy inteligente que había aprendido inglés para ser guía de turistas, ya que éstos concurren en buen número a Chichicastenango ahora. Sebastián podría ser un buen prototipo para el estudio psicológico de un hombre marginal. Desgraciadamente sus fantasías personales y su carencia real de conocimientos acerca de importantes aspectos de la cultura como el sistema de cofradías (en el cual nunca había servido) limitaba mucho su utilidad como informante general, pero servía mucho como compañia en sitios como las casas de cofradia y la capilla del Calvario donde normalmente no se permite la entrada a forasteros. Mucha información sobre acontecimientos recientes y la política local me la proporcionó un residente de origen británico que ha vivido en el pueblo los últimos 18 años. Mi guía en las caminatas hacia los cantones rurales fue un comerciante ladino que hablaba quiché, que había sido el primer regidor en el gobierno municipal ladino y que era muy bien conocido y siempre bien recibido por indígenas de cualquier posición.

\section{Notas bistóricas}

Durante los dos meses que residí en Chichicastenango, mi esposo, el doctor Alan Bryan, realizó un reconocimiento arqueológico de las zonas accesibles del municipio. Conforme a sus inclinaciones particulares, buscó primero sitios precerámicos, halló dos, pero más bien en las elevaciones de las montañas hacia el sur, fuera de las fronteras del municipio, en el Departamento de Totonicapán. Los sitios cerámicos que indicaban pequeños asentamientos existían en gran cantidad dentro del municipio; en muchos lugares uno camina sobre fragmentos cerámicos en los senderos rurales, y podemos suponer la presencia de una relativamente densa población en el pasado prehistórico. La colección de fragmentos no ha sido ampliamente analizada todavía, pero la mayoría de la cerámica parece ser de los tipos del Clásico Tardío o del Posclásico, aunque existe algo de material del Clásico Temprano. Un pequeño "juego de pelota" del Clásico Tardío, con su campo rodeado de terraplenes bajos, se encontró en un cerro muy cerca de la carretera, en el cantón de Chuabaj. Hay muchos grupos de pequeños montículos de edad desconocida. Quizá el sitio más significativo que se visitó, fue el conocido como Cichicastenango Antiguo, que se ubica en el cantón de Chontalá. 
cerca de cuatro kilómetros al este del centro actual del pueblo. Conforme a la tradición, este lugar fue un importante centro quiché a fines de la época prehistórica, una fortaleza en las guerras entre quichés y cakchiqueles. Se ubica en lo alto de una larga cordillera, la que se rodea de una pequeña muralla de piedra y tiene una entrada que sirve de contrafuerte. Dentro del área amurallada existe un grupo de montículos bajos; se han hallado entierros dentro de los montículos, y se informa que algunos se acompañaban de objetos de oro. Santuarios modernos han sido construidos en las bases de varios de los montículos.

Un sitio extenso consistente en varios montículos grandes y elevados fue visitado en el cantón de Los Cerritos, en el pequeño municipio de Santo Tomás Chiché, ubicado junto al noreste de Chichicastenango. El sitio, conocido como Chiché, fue señalado previamente por Wauchope (1948); su edad parece situarse entre el Preclásico Superior y el Clásico Tardío. Como Bunzel ha subrayado, el municipio de Chiché es prácticamente idéntico en lo cultural a Chichicastenango (aunque en menor escala); supe que una vez fue parte del municipio de Chichicastenango hasta fines del siglo pasado y por alguna razón, aun desconocida, las comunidades se separaron. Debe ser importante estudiar las causas y consecuencias de tal separación.

\section{Los cantones}

Gracias al reconocimiento arqueológico y al popular guía e intérprete ladino hablante del quiché, mi esposo y yo pudimos hacer varias caminatas de algunos días hacia los cantones rurales que rodean el pueblo de Chichicastenango, que funge como centro. Hace 40 años no se le permitió a Bunzel ir a tales lugares (Bunzel, 1952: $\mathrm{X}-\mathrm{XI}$ ). Las relaciones indoladinas han mejorado a tal punto que los ladinos pueden viajar ahora a la mayoría de los cantones, pero se nos dijo que hay varios cantones muy conservadores en el lejano oeste (los cantones de Mactzul) donde no se permite entrar a los ladinos y si alguno de éstos lo hace, pone en peligro su vida. Nosotros encontramos que la gente actúa con recelo hacia los extraños en las zonas rurales; afortunadamente para nosotros nuestro guía era bien conocido y recibido, pero en muchas ocasiones se detenía y explicaba nuestra presencia a la gente común con la que topábamos, y también lo hacía con los funcionarios de cada cantón visitado. 
Tal como Bunzel lo ha descrito, hay 64 cantones en el municipio de Chichicastenango: de 32 se dice que están en el este y 32 en el oeste. Los cantones son pequeños: deben contar en promedio cada uno 500 habitantes. En muchos casos cantones adyacentes llevan el mismo nombre pero están numerados (por ejemplo: Chulumal, Chulumalcab, Chulumaloxib, Chulumalcajib, o en español, Chulumal primero, segundo, tercero, cuarto); tal situación sugiere la integración pasada de esos pueblos. Mucha gente de un cantón particular puede tener el mismo apellido, pero no hay señales de una organización formal de linajes. La gente del mismo apellido, según se nos informa, no puede casarse, pero se dice que en los cantones no hay reglas fijas de matrimonio. Es obvio que se necesita una investigación genealógica de la misma manera que una demográfica en cada cantón, ya que hechos demográficos cruciales permanecen desconocidos.

Un mapa topográfico a escala 1:50 000, del Instituto Geográfico, ahora asequible, (Chichicastenango, Guatemala-Hoja 1960-1) sitúa muchos de los cantones pero no indica sus fronteras precisas; se necesitarán informantes para mapear el territorio preciso de cada cantón. Claramente se percibe que cada cantón no ocupa más de cinco kilómetros cuadrados y la mayoría mucho menos. El mapa topográfico señala los patrones de asentamiento rurales, y yo he reproducido parte del mapa (figura 1) para dar alguna indicación de la distribución de las casas. Se puede ver que dentro de cada cantón las casas están dispersas, esparcidas en pequeños grupos conforme a la topografía muy irregular, sin una concentración central compacta. Las casas familiares se ubican al centro de sus campos de cultivo, generalmente sobre terreno plano o en los flancos o la base de los cerros, cuyas cimas son generalmente boscosas.

Un sistema complejo de senderos que se recorren a pie es el más importante medio de comunicación y transporte dentro del municipio de Chichicastenango. Varios caminos mayores, de más de tres o cuatro metros de ancho, parten en varias direcciones desde el centro del pueblo, y son usados por muchos indígenas de otros municipios que viajan a/y desde el mercado de Chichicastenango, así como por los Maxeños que viajan a y desde los cantones. Así, por ejemplo, en día de mercado uno ve muchos sololaltecos en el camino mayor suroeste, ya que esta ruta es más directa que la carretera pavimentada. De estos caminos grandes parten ramas más estrechas que conducen a cada cantón adyacente, y de éstos senderos derivan estrechas veredas que se desvían por los campos o el bosque y llevan a las 
casas familiares o a los santuarios. Los caminos mayores y los que pasan por los cantones se mantienen bien debido al trabajo comunal obligatorio no pagado de hombres y muchachos dentro de cada cantón, que por lo general se efectúa mediante esfuerzos organizados y concertados, utilizándose en él el machete y azadas de amplias hojas; ${ }^{1}$ el trabajo se realiza durante varios días poco después del fin de la estación lluviosa en noviembre. Las orillas adyacentes al camino son cortadas formando un paramento recto; zanjas de desagüe son excavadas transversalmente a las vertientes; cavidades y sitios de suelo blando son llenados con lodo, piedras o ramazón, y en lugares muy empinados (que son muchos) se hacen escalones cuidadosamente cortados en la tierra o la ceniza volcánica endurecida. La importancia de estos trabajos de conservación se comprende cuando se observa la gran cantidad de tránsito humano con bultos pesados que circula por los senderos del municipio.

La organización política de cada municipio responde en gran medida a la descripción de Bunzel (1952: 182-185). Al parecer el individuo más influyente es el principal del cantón, cargo de larga vida que, según se señala, tiende a ser hereditario. Un alcalde auxiliar nombrado por un año por el gobierno municipal indígena y que lleva una vara corta con punta de metal, se presenta ante el alcalde y los regidores de la municipalidad indígena cada domingo en la mañana para informar del estado de cosas en el cantón y recibir las órdenes necesarias de esos funcionarios indígenas, que se hallan en el pueblo. Desde 1955, por otro lado, existe a nivel cantonal una organización policiaco-militar dirigida por el gobierno del Departamento del Quiché. En cada cantón hay ahora un comisionado militar, un indígena local que es nombrado para servir cinco años; esta organización dentro del municipio es encabezada por un capitán militar indígena. El papel preciso y las relaciones que establecen cada uno de estos funcionarios dentro del cantón quedan por definirse en el futuro, mediante otra investigación.

Prácticamente cada familia en un cantón deriva su subsistencia del cultivo del maíz, pero hay numerosas actividades económicas complementarias llevadas a cabo en el cantón. Por lo menos una familia en cada cantón tiene un pequeño molino para maíz, el cual sirve a cada familia del cantón mediante un pequeño cargo por cantidad de maíz llevada. Una familia puede dedicarse al negocio del pan; la materia prima se lleva por cargadores o mulas y el pan prepa-

${ }^{1}$ Los maxeños no usan palas para remover lodo, ni sierras para cortar árboles, siendo ello una característica peculiar suya. 
rado se envía al mercado del pueblo dos veces por semana. Muchas familias en las afueras de los cantones tienen pequeñas tiendas o cantinas agregadas a sus casas, y en los días de mercado cuando numerosas personas viajan por los caminos mayores se venden comidas y refrescos por familias locales en puestos construidos al efecto a lo largo de los caminos.

Uno se lleva la impresión de que hay bastante orgullo comunal y esprit de corps entre la gente de cada cantón. Observé, por ejemplo, que los grupos de danza tradicional o Bailes se organizan y presentan por grupos de hombres jóvenes de cantones particulares que gastan mucho individualmente en los trajes.

No supe de grandes ceremonias religiosas, excepto una misa anual que se celebra a beneficio del cantón en un lugar especialmente construido por el párroco, que sale del pueblo en una fecha fija. No hubo evidencia de ceremonias tales como las descritas llevándose a cabo en los parajes rurales de Zinacantán (Vogt, 1969). Varios o muchos cbuchqajau o hechiceros (no jerarquizados formalmente) viven en cada cantón, pero las ceremonias se realizan sólo por chuchqajau individuales y sólo para el beneficio y por petición específica de familias nucleares particulares. Puede notarse, sin embargo, que al igual que en Chiapas, un ritual se presenta de lugar en lugar: los numerosos sitios sagrados visitados en el curso de una gran ceremonia incluyen por lo general los santuarios dentro del centro del pueblo (iglesia, Calvario, casas de cofradía) y los más importantes sitios sagrados rurales.

\section{Los santuarios rurales}

Nuestras visitas a los cantones nos proporcionaron una excelente oportunidad de observar un buen número de los muchos santuarios rurales. Casi cada casa tiene un altar privado, y siempre hay lo que se denomina altares públicos (aunque siempre ubicados en propiedades privadas), estructuras mayores donde "cualquiera puede cualquier cosa". Cada santuario parece ser conocido por diferente nombre.

Los altares familiares se ubican cerca de los núcleos caseros, o pueden colocarse en el centro de una milpa o en los bosques cercanos. Un altar "público" se halla por lo general en las cimas de los cerros o cordilleras (cuyos alrededores pueden estar cultivados o no). Una determinada serranía puede tener varios santuarios, muy cerca unos de otros. Muchos altares están colocados en las bases de 
grandes árboles viejos. Siempre hay un altar en medio de cada cementerio cantonal.

Aunque hay considerables variaciones en los elementos formales, todos los altares parecen tener el mismo patrón de diseño (figura 2). La parte principal del altar consiste en una plataforma de piedras, frecuentemente escalonada, sobre la cual se colocan ofrendas de velas, pétalos de rosas y caléndulas, y aguardiente (los altares se denominan comúnmente mesas de cbuchqajau). La plataforma está rodeada en tres lados por paredes de piedras rectas, que pueden estar adornadas con ramas de pino. Algunas veces esta plataforma circundada puede ser doble. Frente a la entrada de esta construcción, a veces junto al borde de la plataforma pero generalmente a unos cuantos pies de distancia, está un quemador, donde se queman las ofrendas de copal. ${ }^{2}$ También frente a la plataforma, pero a una distancia mayor, se halla muchas veces un pequeño montón de piedras o una pequeña estructura pétrea que sigue el modelo de la plataforma mayor circundada. Puede pensarse que este patrón común que se expresa en la existencia de una parte menor separada y frente a una mayor se encuentra también en el orden de las estructuras religiosas en el centro del pueblo: la iglesia es como el altar, con el quemador al pie de los escalones frontales, y en el lugar opuesto, cruzando la plaza, está la capilla del Calvario.

Algunos de los altares rurales "públicos" son bastante grandes; la principal plataforma, la del altar en la cima del Poqojil, que se nos dice es el mayor de todos, mide cerca de diez pies de largo y seis de ancho, y la plataforma pétrea escalonada y la pared que la rodea, con sus piedras unidas, alcanzan como altura máxima, en su extremo posterior, cerca de seis pies. El altar opuesto más pequeño, también de piedra siguiendo el mismo modelo, está ubicado a unos doce pies de distancia, frente al grande. La zona entera está ahora cubierta por un albergue de techo de tejas que se extiende unos 20 pies a cada lado de la zona inmediata, la del altar. Se nos indica que este refugio es para alojar a la multitud (incluyendo a Tsijolaj, una pequeña representación de un modelo de caballo y jinete que ahora se halla en el local de la cofradía de Santo Tomás) que viene a la fiesta anual celebrada por el propietario de la tierra en el "cumpleaños de Poqojil" que se nos informa se celebra por abril. Desafortunadamente no conseguí más información acerca de esta ceremonia anual en el más importante altar en una de las más altas

\footnotetext{
2 En un altar en uso, el piso se cubre con las envolturas desechadas de los paquetes de copal, que cuestan 5 centavos y contienen 20 pastillas.
} 
montañas en el municipio, ceremonia al parecer muy importante. Es importante también, en relación a este altar mayor, hacer notar que en un entronque del principal camino sudoccidental con otro que se halla a cerca de un kilómetro y medio al sur de Poqojil hay un altar llamado Xe-Poqojil donde se supone que la gente pide permiso para acercarse a la montaña.

Junto al muro posterior de un altar dado pueden hallarse diversidad de cosas; usualmente se encuentran una o varias cruces de piedra pequeñas y gruesas (se contaron ocho en un altar familiar). Tales cruces se encuentran también señalando algunas tumbas en los cementerios.

En algunas raras ocasiones puede haber un ídolo esculpido en piedra (como en Turqa') o un simple rostro humano grabado en una cruz o en otra piedra. Generalmente hay objetos prehistóricos asociados, pueden ser manos de metate, bolas pétreas perforadas, núcleos de navajas de obsidiana, hachas de piedra pulida, fragmentos de figuras talladas, jarros rotos o grandes tiestos. Se nos indicó que estos objetos se encontraron en los campos y se trajeron a los altares; se coloca junto al muro posterior de las plataformas o en montículos artificiales contiguos.

La asociación estrecha de montículos bajos hechos de piedra o tierra con muchos altares es significativa, ya que tales montículos comúnmente se consideran tumbas. El altar puede ser construido en lo alto de uno de esos montículos o en su base; sin excavaciones es imposible por supuesto señalar cuáles montículos son prehistóricos o si realmente son o no tumbas. Lo importante es que se cree que lo son, y diversas ceremonias en estos altares pueden ser dedicadas a los personajes de las tumbas. Significativamente, en dos de esos altares se nos explicó claramente que las tumbas eran de un kalpul, persona con reputación de juez (cf. Bunzel, 1952: 81). Parece que el llamado a los ancestros, tan importante en las creencias sobrenaturales de los maxeños, no se restringe a los rituales de las casas, iglesias o camposantos tal como Bunzel creyó (1952: 267, 270); también en los altares rurales se les puede invocar. Muchos altares familiares, pertenecientes ahora a catequistas (convertidos al catolicismo ortodoxo romano) han caído en el desuso, si es que no han sido deliberadamente destruidos. Incluso aquellos altares familiares mantenidos todavía por varias gentes no parecen usarse mucho, a menos que su dueño sea un chuchqajau prácticamente. Los altares rurales "públicos" más grandes, sin embargo, todavía se usan con eficiencia, siendo frecuentemente visitados por aquellos que en buen 
número son todavía fieles a la religión tradicional, y lo más común es llegar a uno de ellos y encontrar frescas ofrendas de flores, velas encendidas o copal ardiendo, si no es que una ceremonia en pleno desarrollo.

\section{La fiesta de la Virgen de la Concepción}

Dos fiestas mayores tuvieron lugar de acuerdo a lo establecido en el lapso que residí en Chichicastenango: Todos Santos del 30 de octubre al 2 de noviembre y la Concepción el 8 de diciembre. Las ceremonias de la primera se realizaron conforme a la detallada descripción de Bunzel; sorprendentemente apenas si había modificaciones menores después de 40 años. La Fiesta de la Concepción, sin embargo, no es descrita por Bunzel, y a mí me parece que puede ser muy importante como punto focal de conflicto y competencia entre los ladinos y los indígenas, ya que cada grupo tiene sus propios rituales en la ocasión.

Diez días antes de la fecha de la Concepción, un par de músicos, con tambor y flauta se situaron en la azotea de la iglesia cerca del campanario al norte y tocaron desde cerca de las siete y media de la mañana hasta cerca de las cinco de la tarde cada día. Durante estos días, la iglesia y sus escaleras, las paredes del convento, el Calvario, y la pequeña capilla del cementerio del pueblo recibieron una nueva lechada que realizaron muchos hombres. Al mismo tiempo empezó una limpieza general en el pueblo, con cada casa blanqueada o pintada, y se limpiaron las calles adyacentes empedradas. Se me dijo que un reglamento municipal ordenaba tal limpieza general a los propietarios de casas en anticipo a la Navidad y a la fiesta mayor del pueblo, el día de Santo Tomás, en la tercera semana de diciembre.

El 30 de noviembre la imagen ladina de la Virgen de la Concepción se colocó en un estrado escalonado especial, cubierto de tela, a la izquierda del altar enrejado de la iglesia. ${ }^{3}$ En los días posteriores, vasos con flores ornamentales y pequeñas veladoras de estilo ladino se colocaron ante esta imagen de la Virgen. La imagen misma, hecha en fábrica evidentemente, tenía rasgos faciales muy finos, de muñeca, no como los rasgos planos de las imágenes indígenas de los santos, hechas a mano.

${ }^{3}$ Las imágenes indigenas que se llevan a la iglesia se colocan siempre a lo largo de las paredes en la nave más baja. 
Alrededor de las ocho de la noche del 7 de diciembre esta imagen fue llevada en una procesión de una hora por las principales calles del pueblo. Tanto en detalles de organización como de realización, la procesión difería marcadamente de las procesiones religiosas indígenas: se componía sólo de ladinos con unos cuantos indígenas a la retaguardia, que parecían más espectadores que participantes. La vanguardia de la procesión la componían hombres que prendían cohetes así como buscapiés en cada esquina de las calles; hay que destacar que los fuegos artificiales se prendían mucho antes de la llegada de la procesión, la cual no se interrumpía; en cambio, en las procesiones indígenas, si ésta llega a una esquina y detiene su marcha, la imagen transportada se baja y entonces se encienden los fuegos artificiales.

Un tamborilero y un flautista venían al frente de la procesión ladina, pero el tambor tocaba un ritmo peculiar, diferente de la música de las procesiones indígenas. Después venía un hombre portando en alto una lámpara de gasolina para iluminar la imagen de la Virgen colocada en andas decoradas de flores. Detrás de la imagen estaba un hombre vestido con un buen traje ladino, leyendo en alta voz un libro abierto que llevaba en la mano. Venían después dos filas de personas, principalmente mujeres, llevando cada una de esas personas una vela grande. Había también en la vanguardia una pequeña banda con instrumentos musicales brillantemente pintados.

Mientras la procesión circulaba por el pueblo, una multitud considerable de ladinos esperaba en la plaza frente al Edificio $\mathrm{Mu}$ nicipal, donde la marimba oficial tocaba en el pórtico. Parecía que pocos indígenas se encontraban allí. Un grupo de niños ladinos disparaba pequeños cohetes desde las escaleras de la iglesia, encendiéndolos de una doble fila de velas que se hallaban, como es usual, en la entrada de la iglesia. La imagen de la Virgen volvió a su lugar en la iglesia donde permanecía hasta después de nuestra salida el 11 de diciembre.

El Día de la Virgen de la Concepción, al día siguiente, el 8 de diciembre, fue como un día festivo en Chichicastenango. Algunas tiendas cerraron, y muchos ladinos deambularon por la plaza y las calles. Durante el día pequeños y numerosos grupos de ladinos, quizá familias, visitaron la iglesia.

En ese día dos diferentes grupos de danza, uno indígena y otro ladino, actuaron alternadamente o en sitios diferentes, primero en la plaza, luego en las calles y en las casas privilegiadas del pueblo. 
Al grupo indígena de danza lo seguían al parecer principalmente indígenas, y al grupo ladino, principalmente ladinos.

El grupo indígena, acompañado por la banda de marimba del cantón de Sepelá (ubicado al norte del pueblo), consistía en una fila doble y larga de danzantes enmascarados vestidos con los trajes de los diversos municipios indígenas de los Altos de Guatemala. Los danzantes, que llevaban máscaras de madera pintadas y turbantes al estilo de los bailarines de los Bailes tradicionales, formaban parejas masculinas y "femeninas"; éstas llevaban pelucas y blusas muy bien rellenadas. Las danzas que ejecutaban en fila, eran más bien de carácter ladino, los danzantes se tomaban de las manos o los brazos y entre los aires reconocidos estaban la danza de la serpiente y la rumba. El jefe de los danzantes, el hombre a la cabeza de la doble fila, indicaba los cambios en los pasos con un silbato de metal metido en la boca de su máscara. Cuando el grupo se movía, la procesión era desviada por un hombre con traje ladino que portaba una vara no usual, de unos dos pies de largo, con un mango que era una campana invertida de papel crepé azul y blanco, y arriba una base sosteniendo una pequeña figura femenina con túnicas largas, apoyada contra una estrella grande: posiblemente una representación de la Virgen de la Concepción. ${ }^{4}$

Cuando el grupo indígena de danza entró primero al pueblo proveniente del sur hacia las siete y media de la mañana, venía en una procesión de doble fila que se dirigió primero al local de la cofradía de Santo Tomás, donde los miembros del grupo actuaron en un círculo dentro del patio, cerca de media hora antes de que todos los danzantes y la banda fueran admitidos a la sala, posiblemente para presentar sus respetos a la imagen del santo patrón del municipio. De ahí se dirigieron a la plaza para iniciar las actuaciones públicas. Alrededor de las seis de la tarde después de su actuación final en una casa privada, el grupo retornó una vez más al local de la confradía de Santo Tomás (algunos lo hicieron dificultosamente; el hombre de la vara ya estaba por supuesto completamente borracho para entonces).

El grupo de danza ladino hizo su primera aparición en la plaza alrededor de las ocho y media de la mañana; venía del norte, justo cuando el grupo indigena terminó su primera actuación pública y se dirigía al norte, seguido por una multitud de indígenas. La banda de marimba acompañante del grupo de danza ladino, con

\footnotetext{
' El simbolismo de la Navidad cra también visible en las decoraciones de la imagen ladina de la Virgen de la Concepción.
} 
todos sus miembros vestidos con trajes elegantes, subió a un gran camión que seguía a los danzantes. Había menos parejas de bailarines que en el grupo indígena, y los ladinos vestían con trajes más elaborados y excéntricos, con máscaras de cartón piedra: caricaturas bien logradas de soldados, una joven vestida con moda de la alta sociedad, un hombre corpulento con chaleco y bombín, una vieja (¿turista?), un cartero, un telegrafista, dos jipis, dos monjes, dos hombres de las cavernas, dos ratones blancos, un árabe y un "Pron-tito" del anuncio de Alka-Seltzer.

El grupo de danza ladino actuó en la plaza por unos veinte minutos; luego, como el grupo indígena se retiró seguido por una multitud para actuar en diferentes lugares en las calles y en las casas privadas por el resto del día.

Como a las nueve y media de la mañana, la procesión con la imagen indígena de la Virgen de la Concepción dejó la iglesia. La imagen debió haber sido llevada a la iglesia por su cofradía el día anterior, pero no me enteré de ello. La procesión, teniendo al frente la flauta y el tambor usuales, llevaba dos pequeñas imágenes apoyadas contra grandes rayos de madera pintados y con paquetes de velas sobre las andas portadoras. La marcha pasó alrededor de la plaza hacia el norte, pasó por el Edificio Municipal, y volvió entonces hacia el oeste, al local de la cofradía. Concepción es una de las cofradías de más bajo rango en Chichicastenango (Bunzel la puso en onceavo lugar). Ninguna multitud siguió a la vanguardia después de la procesión, y ninguno de los participantes llevaba el traje típico maxeño que por lo general lleva el mayordomo de una cofradía. Es de notarse que algunos de los participantes en la fiesta estaban de un humor irritable, hostilizaban a los fotógrafos y uno, muy borracho, quería 50 centavos por foto ("para velas"). Un turista que se acercó mucho a la procesión fue casi lanzado a empujones. Fue la primera y única vez que observé una acción hostil abierta contra los no-indígenas por parte de cualquier maxeño. Me pareciö que la fiesta de la Concepción fue un periodo de tensión entre los indígenas y los ladinos; es la única fiesta importante del pueblo en la cual los ladinos juegan el papel principal; todas las otras son promovidas por los indígenas en beneficio de las imágenes de sus santos.

Es en esta época cuando la competencia es evidente entre los dos grupos de danza y las dos procesiones por separado de diferentes imágenes de la Virgen; y en esta ocasión los ladinos se llevan el galardón. 


\section{Cambios recientes}

Para una persona familiarizada con la monografía de Bunzel que describe la escena hace 40 años, lo más notable en el actual Chichicastenango es el grado de persistencia de la cultura tradicional. Se mantiene el gobierno municipal dual de las jerarquías ladina e indígena; continúa el sistema de cofradías en todo el colorido de la manifestación; el mercado con sus bullicios, más grande que cuando Bunzel vino, se realiza dos veces a la semana, y continúa diariamente la celebración de las tradicionales costumbres por parte de los individuos en particular así como de los chuchqajau, con hileras de velas sobre el tablado, en el lugar de las almas, en la nave de la iglesia, y gran humareda de incienso en los escalones de la misma.

Por supuesto, el cambio se ha dado, y más aún parece que se dará en el futuro inmediato. Elementos materiales de origen ladino han penetrado en la cultura maxeña en años recientes, y ha habido presiones fuertes y persistentes en pro del cambio, inducidas por fuerzas políticas extrañas y en especial por fuerzas religiosas. La situación actual es muy interesante, y lamento no haber tenido tiempo de investigar las complejas implicaciones de los cambios observados y aquellas de las que se nos informó.

Las cosas materiales tomadas del mundo ladino son los más obvios elementos. Los radios portátiles se oyen ahora en cantones remotos; muchos tienen cosas como bicicletas y relojes de pulso, y los recipientes y utensilios de plástico o metal se usan en cada casa. Casi todos los hombres usan trajes ladinos; sólo los más viejos o los que tienen puestos políticos o religiosos pueden ser vistos ahora portando el tradicional traje masculino de cortos pantalones negros de lana y camisa bordada.

Recabé varias opiniones acerca del cambio general en el traje masculino. Sebastián creía que tal situación se debía a que el pueblo "se había echado a perder" (o sea, ladinizado). Además, él y sus amigos constantemente señalaban que el traje tradicional completo era muy caro (cerca de 90 quetzales, o sea, 90 dólares); la ropa ladina era mucho más barata y fácil de comprar. Incluso en tiempos de Bunzel la ropa era muy cara. Un joven de Chiché me dijo que los jóvenes ahora llevan ropa ladina casi exclusivamente porque las muchachas les insisten a tal efecto, considerando que el traje masculino tradicional ha pasado de moda; de otro modo, muchos llevarían ese tipo de traje. Sin embargo, todas las muchachas y mujeres indígenas, todavía usan el vestido tradicional completo. 
La venta de ropa ladina de hombre ha sido uno de los más importantes factores en el crecimiento físico del mercado que se realiza dos veces a la semana en el pueblo. Varios puestos, la mayor parte ubicados en la esquina noreste del mercado, venden ahora pantalones, camisas, suéteres, chaquetas, calcetines, sombreros y zapatos (los últimos se adaptan a pies sensibles quitando parte del tacón). Incluso partes del vestido tradicional femenino - blusas, faldas y fajas- pueden comprarse en algunos puestos en el sector norte central del mercado.

No tuve tiempo de realizar un estudio económico, pero parecería que en este campo los maxeños en general lo están haciendo muy bien. Varios indios son relativamente ricos, según los niveles ladinos. Un aspecto importante de la situación económica actual es el incremento de la producción agrícola en los últimos años debido al ahora común uso de los fertilizantes químicos, que se venden en el mercado cuando se necesitan. La diferencia observable en las milpas adyacentes, unas con abono y otras sin abono, es grande. Aunque la introducción de fertilizantes químicos fue exitosa, un tipo nuevo de semillas podría no ser aceptado: un campesino maxeño cree firmemente que sólo su propio maíz es apropiado para su tierra.

En conexión con el sistema agrícola, debe mencionarse que aparentemente ha habido un cambio en los conceptos de tenencia de la tierra; ahora se dice que es mucho más fácil vender o comprar tierras.

En tiempos de Bunzel la venta de la tierra se consideraba un grave pecado contra los ancestros. Ahora parece que es posible para un indígena vender o comprar tierras si es necesario, sin muchos problemas. Las implicaciones sociales, religiosas y económicas de este cambio deben ser estudiadas.

Otro aspecto de la situación económica actual es el creciente ingreso de indígenas al comercio local. Los maxeños siempre han sido tenderos y comerciantes; pero ahora parece que se dedican a una mayor variedad de negocios y en mayor número de individuos. Hay muchos panaderos y carniceros. En gran medida la mayoría de los vendedores en los puestos del mercado, incluso en lo que se refiere a artículos ladinos, son indígenas. Varias cantinas y tiendas del pueblo, incluyendo una farmacia, son de propiedad indígena. Se me dijo que un hombre que todavía vive en su cantón es propietario de un restaurante en la ciudad de Guatemala. Al menos una de las líneas de autobuses que pasan por Chichicastenango es de propiedad indígena maxeña, y los indígenas tienen también camiones de carga. 
Un resultado de esta situación, tal como Sebastián alegremente lo señaló, es que en muchos casos los indígenas emplean ahora ladinos.

El acceso a la educación elemental formal se ha incrementado tremendamente en los últimos 20 años. Ahora hay varias escuelas bien atendidas en el mismo pueblo; y la mayoría de los cantones tienen ahora su propia escuela. La mayor parte de los maestros, según se nos dijo, son ladinos. En las escuelas rurales en particular se hace especial énfasis en la adquisición de la capacidad de leer y escribir, y en el español, política que ha dado como efecto un bilingüismo compartido por jóvenes y niños en edad escolar.

La escuela indígena más grande es la establecida y dirigida por el sacerdote católico romano, aunque ahora pertenece legalmente a la comunidad. Tiene un gran terreno en la periferia septentrional del pueblo y cuenta con unos 800 estudiantes, con internos tanto de otros municipios como de Chichicastenango. Tiene una clínica médica adjunta. La organización recibe fondos de grupos filantrópicos de los Estados Unidos, y por lo general cada domingo se realiza una danza infantil en el patio de la iglesia con objeto de obtener fondos de los turistas.

No pude estudiar especialmente la familia indígena, y lamentablemente no puedo proporcionar ningún dato acerca de posibles cambios en la rígida estructura familiar patrilineal que describió Bunzel. Observé que los patrones tradicionales de cortejo y matrimonio parecen continuar; si un joven quiere ganar el respeto de la familia de la muchacha que desea debe emplear aún los servicios de un chimintal, un hombre respetable que sirve como su intermediario y arregla el matrimonio.

La situación política actual en el pueblo es compleja. Las formas tradicionales se mantienen en el nivel municipal, con una organización ladina (el gobierno municipal oficial) electo por voto popular cada cuatro años, y la jerarquía indígena escogida por las autoridades indigenas cada año. Ambas parecen seguir funcionando como lo señaló Bunzel, excepto en lo que se refiere al abandono del sistema de alguaciles, jóvenes indígenas que se reclutaban para trabajos generales secundarios. Actualmente las relaciones entre ambas organizaciones parecen ser buenas, y el enlace principal es el Secretario Indigena, individuo muy astuto y de conocimientos que tiene el puesto permanentemente.

$\mathrm{Ha}$ habido un cambio entre los principales del pueblo, que conforme a lo indicado por Bunzel nombran directamente a los funcionarios políticos y religiosos indígenas. Bunzel indicó que había cinco: 
ahora se informa sólo de dos, uno que jefatura los 32 cantones del este y el otro los 32 del oeste; se nos informó que un principal primero fue depuesto hace varios años por sacar dinero a la gente. Se dice que las decisiones más importantes las toman esos dos hombres conjuntamente, en consulta con todos los principales del cantón, alcaldes auxiliares, y comisionados militares, así como con otros prominentes hombres del pueblo. Los dos principales del pueblo representan a la comunidad indígena ante el presidente de la República cuando ello se necesita.

Llama la atención el que el gobierno municipal ladino todavía no tenga control directo sobre el territorio rural del municipio. Los alcaldes auxiliares de los cantones informan directamente $a / y$ reciben órdenes de la Municipalidad Indígena. El organismo policiaco-militar, compuesto de los indígenas locales en los cantones, está bajo dirección del gobierno departamental en Santa Cruz del Quiché. Este organismo ha creado un nuevo puesto político en el municipio, el de capitán militar, cuyo papel preciso está por definir, pero es de notar que el individuo que lo ocupaba, siempre pulcramente vestido con un traje ladino, tenía prominentes funciones tradicionales: tenía la responsabilidad mayor en los preparativos para un ensayo de un Baile, el que se realizó en el cantón de Saquiyacab el 7 de noviembre, y en su celebración en la plaza del pueblo el domingo siguiente; su presencia se hizo notar también en el local de la cofradía de Santo Tomás, a la llegada del grupo indígena de danza en la mañana de la fiesta de la Virgen de la Concepción. Este individuo parece identificarse con la cultura tradicional y con las autoridades indígenas tradicionales.

Los indígenas que se toman la molestia de registrarse pueden votar en las elecciones municipales y nacionales. Parece que en años recientes el gobierno municipal ladino ha complacido más a la población indígena, construyendo escuelas y puentes en los cantones, quizá en reconocimiento de la mayor afluencia de votos indígenas. Parecería inevitable que un indígena llegue alguna vez próxima a ser electo jefe del gobierno municipal ladino; mas tal situación puede causar problemas serios por la índole de las relaciones ladinoindígenas: la inseguridad que se produciría de parte de la minoría ladina ante las masas indígenas; y por otra parte, el hecho de que se precisa una buena articulación entre el gobierno municipal oficial, el gobierno ladino departamental y el gobierno nacional. Los resultados dependen mucho del carácter y habilidades de los individuos elegidos. 
Durante mi estancia en Chichicastenango la campaña política nacional para las elecciones de marzo de 1970 estaba ya en marcha. Todos los partidos políticos nacionales de importancia tenían organismos funcionando tanto en los cantones como en el pueblo, y algunos indígenas participaban en ellos con funciones y puestos importantes. Sería necesario un análisis detallado para formular conclusiones sólidas acerca de las orientaciones políticas actuales en Chichicastenango. Hallé la situación imposible de caracterizar en términos simples. Me enteré que hubo muchos votantes indígenas en las elecciones de marzo de 1970; Arana triunfó en el municipio por abrumadora mayoría. Por otro lado, la alcaldía municipal se ganó hábilmente, según se alega, por el candidato de la Democracia Cristiana, pero éste no pudo tomar posesión debido a una maniobra del candidato del Partido Revolucionario, y para el 15 de agosto de 1970 el asunto todavía estaba en los tribunales.

La mayor fuerza transformadora actualmente entre la población indígena de Chichicastenango es la de Acción Católica; el objetivo formal de esta organización es convertir a los indígenas al catolicismo romano ortodoxo, asociado ello con el concepto de progreso en otros campos. Este trabajo ha sido y es ahora un punto focal de conflicto entre conservadores y progresistas en el municipio. Desde que llegó a éste en 1951, Acción Católica (cuyos miembros son llamados catequistas) ha desacreditado y atacado activamente la religión tradicional "pagana", y a este fin ha dedicado más hechos que palabras. Una noche de marzo de 1957 un grupo de catequistas invadió el famoso santuario de Turqa', y rompieron el ídolo, arrojaron las piedras por las faldas del cerro e incendiaron la cima. Varios individuos conservadores cooperaron con el dueño del altar en su restauración. Tales intrusiones en los más grandes altares "públicos" han cesado; pero la destrucción de los altares familiares ha aumentado paralelamente con el incremento de los conversos.

Aunque Acción Católica había empezado sus trabajos antes de la llegada del actual cura párroco, éste está ahora envuelto en la situación. Este cura parece ser muy diferente del padre Rossbach. ${ }^{5}$ Venido de España hacia 1960 , no muestra simpatía por la religión tradicional. Después de que realizó varios intentos violentos de eliminar las costumbres en la nave de la iglesia, y debido a un rumor en el sen-

5 La tumba del padre Rossbach, dentro de un gran sepulcro amarillo entre tumbas indigenas en el extremo occidental del cementerio del pueblo, es ofrendada con velas, pétalos de rosa y caléndulas por parte de los indígenas; existe un quemador a pocos pies de la puerta. Parece que la religión tradicional maxeña es todavía eficaz: los viejos patrones pueden ser aplicados en una situación nueva. 
tido de que quería abolir las cofradías, una muchedumbre armada con garrotes asaltó la iglesia una noche; el cura procuró escaparse a la ciudad de Guatemala. Una delegación de prominentes hombres del pueblo fue a quejarse directamente a la capital con el presidente de la República, pero el cura se las arregló para apaciguarlos y después de unos cuantos meses el párroco regresó a Chichicastenango, con una guardia policiaca armada que lo resguardó por algún tiempo.

A consecuencia de este incidente, la práctica de la religión tradicional no puede ser directamente rechazada por el cura, según parece. Las costumbres se celebran con todo vigor dentro y alrededor de la iglesia (que pertenece legalmente a la Municipalidad Indígena y no a las autoridades eclesiásticas), y las cofradías también funcionan plenamente. Sin embargo, el cura no parece participar personalmente, celebra las misas y no más. Los responsos en el lugar de las almas, en la nave de la iglesia, son rezados por un sacerdote auxiliar. Sería interesante ver lo que sucede ahora en las ceremonias de Semana Santa, especialmente las del viernes, cuando se necesita la cooperación del sacerdote en el ritual tradicional (cf. Bunzel, 1952: 218-221).

El párroco y su organización aparentemente se han embarcado en una guerra de desgaste, habiéndose concentrado en la conversión de jefes de familia (y con éstos, las familias enteras) a la ortodoxia. En muchos cantones hay organizaciones locales de Acción Católica. Algunos cantones tienen un alto porcentaje de catequistas, y hay informes de conflictos abiertos entre éstos y los conservadores. El número total de catequistas se estima ahora en 4000 , en una población total de 40000 habitantes en el municipio; ahora cada domingo varios centenares de indígenas van a misa y reciben la eucaristía. $^{6}$

Se necesita un estudio de las motivaciones de los miembros individuales de Acción Católica y de los efectos de su conversión; un sentimiento de orgullo militante es frecuente entre ellos. Ellos son ahora, teóricamente, católicos romanos ortodoxos en sus creencias y prácticas (por lo demás, un estudio de las "recaídas" en las prácticas tradicionales sería interesante). Niegan las concepciones de la reli-

\footnotetext{
- En Chichicastenango, uno y el mismo edificio, la iglesia, es usado al mismo tiempo por las dos religiones. Los tradicionalistas conceden el edificio a los ortodoxos sólo durante la celebración de la misa, en la cual se trasladan los estrados con velas encendidas, del corredor hacia un lado de la nave, donde se apilan. Cuando termina el rito ortodoxo, inmediatamente los estrados vuelven a colocarse y usarse y apenas el cura está dejando el altar cuando el chuchqajau y sus seguidores llegan ahí mismo con ofrendas en mano, envueltas en tela.
} 
gión tradicional, nunca practican las ceremonias nativas, ni solicitan los servicios de los chuchqajau, ni participan en las cofradías, así como tampoco solicitan la bendición de los principales mayordomos en las ceremonias funerales. Pero, significativamente, aunque han rechazado la religión tradicional, se consideran todavía como indígenas, actúan y visten como tales y no ingresan a la sociedad ladina. Es notable el hecho de que los catequistas indígenas no participaran en la procesión ladina de la Virgen de la Concepción. El desdén general por los ladinos continúa muy fuerte en Chichicastenango, incluso entre aquellos que tienen influencias ladinas. Todavía hay gran orgullo en ser indio, y en ser maxeño.

Pese al desarrollo reciente de las actividades de Acción Católica, no puede subestimarse el fortalecimiento continuo de la religión tradicional. ${ }^{7}$ Incluso después de casi 20 años de presiones de Acción Católica y otras organizaciones evangelistas, la gran mayoría de los indígenas conserva las costumbres. Es particularmente notable el hecho de que muchos jóvenes adultos se sirvan de los chuchqajau para ceremonias no sólo en la esfera familiar sino en la de los negocios, y muchos chuchqajau activos en la actualidad son jóvenes adultos.

El compromiso de muchos jóvenes maxeños con las prácticas tradicionales me pareció muy nítido en un ensayo para un tradicional Baile (el Baile de los Toritos) efectuado en la casa del principal del cantón de Saquiyacab a principios de noviembre. El grupo de unos 30 danzantes lo formaban hombres jóvenes del cantón, la mayoría especializados en la venta de carne. Todos se hallaban muy elegantemente vestidos con buena ropa ladina, incluyendo zapatos y relojes de pulsera. A primera vista parecían ladinizados, pero no era así. El ensayo se efectuó con todos los rituales tradicionales para estas ocasiones, con los servicios de un chuchqajau que realizaba ceremonias pidiendo el consentimiento y la bendición del Mundo para asegurar el éxito de la danza y el bienestar de los participantes. A medida que los jóvenes elegantemente vestidos giraban alrededor del cbuchqajau ofreciendo incienso e invocando a las cuatro direcciones, uno se veía forzado a reflexionar sobre la continuidad de los valores básicos de los maxeños bajo un disfraz de elementos materiales ladinos.

Había indicios de algunos cambios en el sistema de cofradías, pero, careciendo de un informante conocedor, me hallaba incapacitada para analizar la situación plenamente tal como se necesitaba. Las 14 co-

"La fuerte persistencia de la religión tradicional se comprendería mejor con un conocimiento más profundo de sus concepciones. Para ello se necesita un investigador que hable quiché. 
fradías parecían estar florecientes, y sus ceremoniales se llevan a cabo de acuerdo a planes que consideran muchos gastos de energía, tiempo y dinero durante las fiestas. Cada año en el municipio el consumo de cohetes se da por millares. En especial, los tronos o andas portadoras para los santos mayores (Santo Tomás, San José y San Sebastián), que se fabrican de nuevo cada año, se han hecho más grandes e incluso con una decoración más elaborada año por año (comparando 1969 con 1967).

Las cofradías mayores parecen funcionar plenamente, pero hay alguna evidencia de que las cofradías de rango menor probablemente no lo están haciendo muy bien. Cuando llegué a principios de octubre había en la nave baja de la iglesia tres pequeñas imágenes de santos (identificadas de modo distinto por diferentes informantes, cuya ignorancia de los santos menores es importante en sí misma). Estaban allí, sin resguardo aunque atendidas e invocadas, hasta cierta mañana de un lunes a mediados de noviembre, cuando un pequeño grupo de mayordomos y sus esposas con trajes ceremoniales se las llevaron en una procesión adecuada a la casa de un individuo que aparentemente había aceptado por fin su elección como primer mayordomo. Me parece que las cofradías de rango menor están teniendo problemas para reclutar funcionarios. Tal como Bunzel lo señaló, siempre ha sido difícil persuadir a los individuos para que acepten un cargo de gravosa responsabilidad en una cofradía; y todavía se escuchan las mismas quejas acerca del gran gasto en tiempo y dinero. Se necesita un estudio detallado y completo de la motivación individual para servir y su relación con los actuales factores económicos, políticos, sociales y religiosos. Uno puede suponer que si las dificultades en el reclutamiento de mayordomos continúan, las cofradías menores podrían unirse, o bien las imágenes de santos a cargo de algunas de ellas podrían quedar bajo el cuidado de otras (de hecho, como Bunzel observó, algunas cofradías tienen varias imágenes en custodia). En esa forma las cofradías menores podrían eventualmente desaparecer, y la atención podría concentrarse en las siempre más prestigiosas cofradías de santos mayores.

Observé que las cofradías se allegan fondos de un modo que Bunzel no describió. Una mañana de domingo una cofradía puede solicitar contribuciones del público en general en el mercado. Alrededor de las diez de la mañana los mayordomos vienen en formal procesión, con tambor, flauta y cohetes, y se dirigen al edificio de la Municipalidad Indígena para recabar el debido permiso para emprender una colecta. Entonces se dispersan por el mercado, algunos 
recorren sistemáticamente puesto por puesto, y otros se colocan en las calles de acceso a la plaza. Todos llevan un sombrero de paja negro que los distingue, sobre su cabeza envuelta en un pañolón, y llevan una vara especial que muestran a la gente para ser venerada. Se espera que por este privilegio la gente colocará una moneda en una tela coloreada portada por el mayordomo. Al mediodía los mayordomos se vuelven a juntar y retornar en procesión formal al local de la cofradía con lo que han recolectado (lo que obviamente incluye algunas libaciones de aguardiente). Esta costumbre ${ }^{8}$ ahora parece ser común en las semanas que preceden a una fiesta mayor; la cofradía de San Miguel realizó tal colecta en el mercado antes de la fiesta de Todos Santos, y en las últimas semanas de noviembre varias cofradías la solicitaron. Parece que éste es un modo idóneo de aumentar los recursos financieros de los miembros particulares de una cofradía.

\section{Turismo}

Las coloridas actividades de Chichicastenango y el fácil acceso a este lugar desde la ciudad de Guatemala (dos horas por una ruta pavimentada) lo han hecho un gran centro de interés para el turismo europeo y angloamericano. Prácticamente cada agencia de viajes que tenga importancia en la ciudad dirige una jira hacia el mercado dos veces a la semana. Hay un hotel de lujo en Chichicastenango (una pensión más modesta se ignora por lo general) al cual se lleva a los turistas en autos privados por guías ladinos de la ciudad que hablan inglés. Incluso en un día normal de mercado ( grande) se ven 50 o más turistas alrededor del pueblo.

Parecería que la mayor parte de las ganancias inmediatas provenientes del turismo va a manos del ladino propietario del hotel y a los guías ladinos. Sebastián y un amigo suyo quieren ser guías de turistas en la plaza, pero con frecuencia están borrachos y por ello no tienen éxito. Es de hacerse notar, sin embargo, que la mayoría de los vendedores de los textiles hechos especialmente para turistas, cuidadosamente exhibidos en los muchos puestos ahora colocados en la parte occidental de la plaza, son indígenas, y hacen muy bien sus operaciones. También los vendedores ambulantes indígenas de más-

\footnotetext{
${ }^{8}$ Aunque Bunzel no la registra, creo que la costumbre es vieja. Muy recientemente vi una ilustración del mismo procedimiento de veneración y contribución en un grabado brasileño de inicios del siglo XIX.
} 
caras, "ídolos", collares y otras chucherías acometen a los turistas exitosamente. Pero aparte de estas gentes, la población indígena no obtiene ganancias directas del turismo.

Con pocas excepciones (y es de notarse que la mayoría de éstas se refieren a europeos) la mayor parte de los turistas en Chichicastenango actúan con ignorancia y odiosamente. Su práctica común es la fotografía indiscriminada, incluso frecuentemente dentro de la iglesia; aunque muy pocos turistas parecen tener alguna idea real de lo que están viendo y registrando. Las informaciones de los guías ladinos sirven de poco para estos casos y no ayudan a la comprensión, ya que por lo general expresan sus propios prejuicios y su intolerancia respecto a las costumbres indígenas, con interpretaciones erróneas o distorsionadas. Es lamentable para todos que los visitantes no cuenten con fuentes correctas de información.

La reacción indígena habitual frente a la invasión bisemanal de gentes extrañas parece ser la de ignorar a los turistas y seguir adelante con sus ocupaciones, vendiendo artículos o portando quemadores de incienso pese a la proximidad de cámaras tomando fotografías instantáneas. El miedo inicial a los extraños (la palabra quiché usada para referirse a los turistas significa literalmente "caníbal" y se sigue empleando) ha sido sustituido por el desdén. En la práctica los turistas restringen su movimiento a la plaza, la iglesia y su explanada, el camino al altar de Turqa' y la casa de un fabricante de máscaras que se halla en ese camino. Los turistas no se aproximan mucho al Calvario, del cual se les aleja y tampoco se les permite entrar al local de una cofradía incluso durante las fiestas (a menos que Sebastián o su amigo sean los guías). Salvo la danza de los niños de la escuela católica, que se efectúa en el patio de la iglesia, no se representa ninguna ceremonia expresamente para los turistas. Los rituales privados, Bailes tradicionales y las fiestas de las cofradías se celebran en el tiempo habitual, sin consideración para los turistas. Contrariamente a lo que se dice, la vida en Chichicastenango no ha sido echada a perder por el turismo.

Ya en un análisis amplio de la situación, uno puede considerar que el turismo ha provocado más bién el reforzamiento de la cultura indígena tradicional que su amortiguamiento. Significativamente, la delegación indígena que fue con el Presidente de la República a quejarse por lo del cura señaló que si las costumbres se eliminaran en Chichicastenango con ello se perjudicaría la industria turística nacional. Esto lo pueden alegar siempre los conservadores frente a la presión directa de los renovadores. Pero debe señalarse que, aun- 
que el turismo puede servir para proteger la cultura tradicional en Chichicastenango, no puede explicar por sí solo la persistencia de tal cultura.

\section{Conclusiones}

En este informe he indicado muchos aspectos de la cultura maxeña contemporánea que necesitan una investigación y un análisis detallados. Chichicastenango se encuentra maduro para un reestudio. El espléndido y detallado trabajo de Bunzel provee de una base firme al análisis de los cambios en este largo plazo, y muchos cambios que ahora se desarrollan pueden observarse realmente.

Actualmente es relativamente fácil para los antropólogos desplazarse en Chichicastenango; la gente se ha habituado a los extraños y mostrar un interés genuino en la cultura puede abrir la mayoría de las puertas. Es dudoso, sin embargo, que una irrupción masiva como la que implicó el Proyecto Chiapas, con su gran número de investigadores, pueda ser bien recibida en el municipio actualmente. Una o dos personas, preparadas para estar por un largo periodo necesario para establecer firmes contactos personales requeridos para recoger los detalles completos de muchos aspectos de la cultura, parece ser una opción más idónea. Tomaría bastante tiempo, por ejemplo, para que un extranjero llegara a ser lo suficientemente aceptado para que se le permitiera residir en un cantón.

Al igual que otras comunidades indígenas en la América Media, Chichicastenango ha estado expuesto a poderosas influencias del exterior en años recientes, y sin embargo la cultura tradicional persiste en sus elementos esenciales. El municipio puede ser modernizado sin perder su alma. Este extraño fenómeno amerita estudio.

\section{RECONOCIMIENTOS}

Este estudio fue posible gracias a una subvención de la Universidad de Alberta y a una beca del Canada Council. Agradezco la cooperación del Instituto Indigenista Nacional, del Seminario de Integración Social Guatemalteca y del Instituto de Antropología e Historia de Guatemala; y agradezco profundamente la hospitalidad y cortesía de los funcionarios y ciudadanos del municipio de Chichicastenango. 


\section{BIBLIOGRAFÍA}

BUNZEL, RUTH

1952 Chichicastenango: A Guatemala Village. Publications of the American Ethnological Society, vol. 22. University of Washington Press. Seattle.

VOGT, EVON Z.

1969 Zinacantan: A Maya Community in the Highlands of Chiapas. Harvard University Press. Cambridge, Mass.

WAUCHOPE, ROBERT

1948 Surface Collection at Chiche, Guatemala. Middle American Research Records, vol. 1 , núm. 10, pp. 123-150. Tulane University, Middle American Research Institute, New Orleans. 


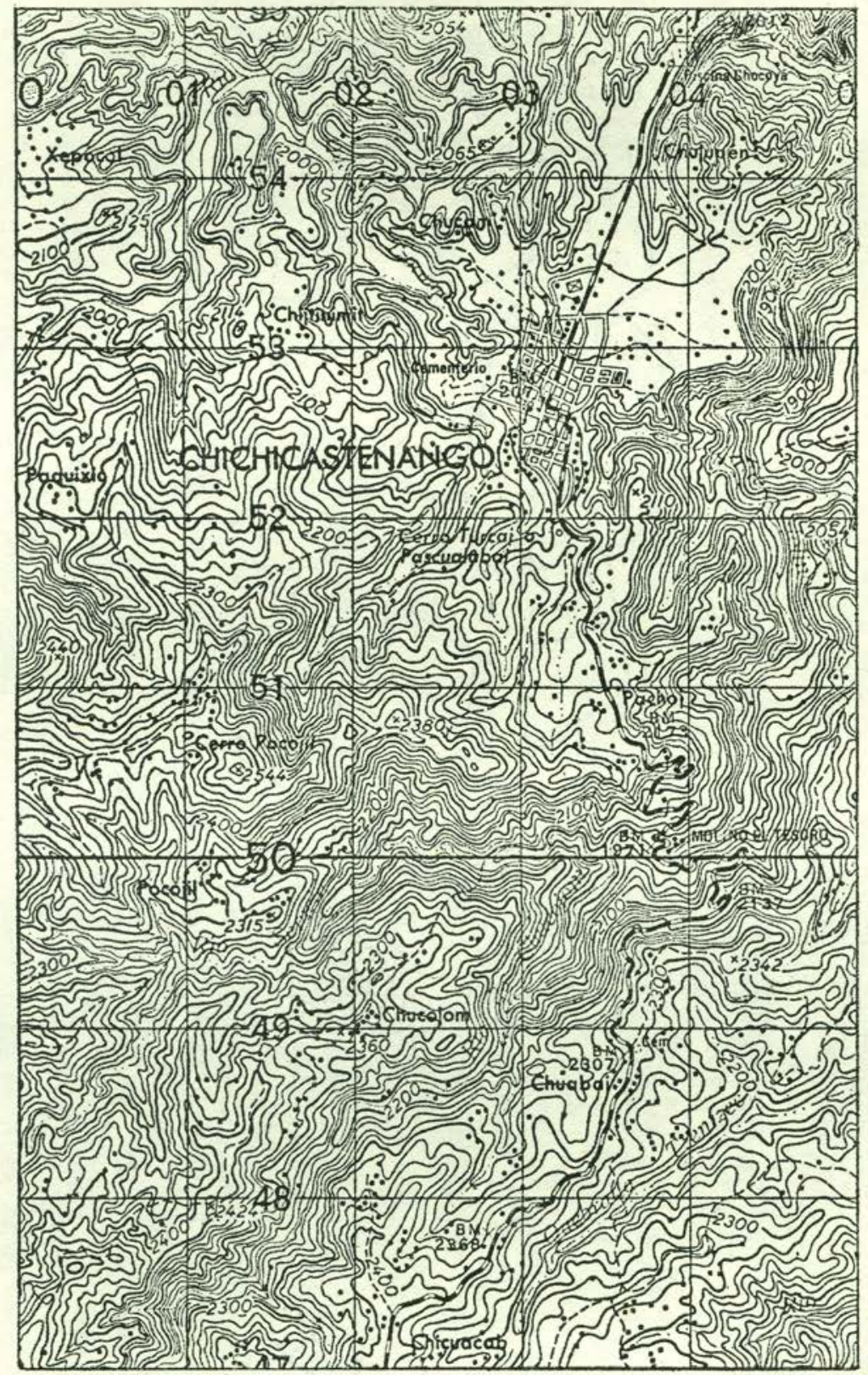

Figura 1. Mapa de parte del municipio de Chichicastenango, señalando los patrones de asentamiento. 

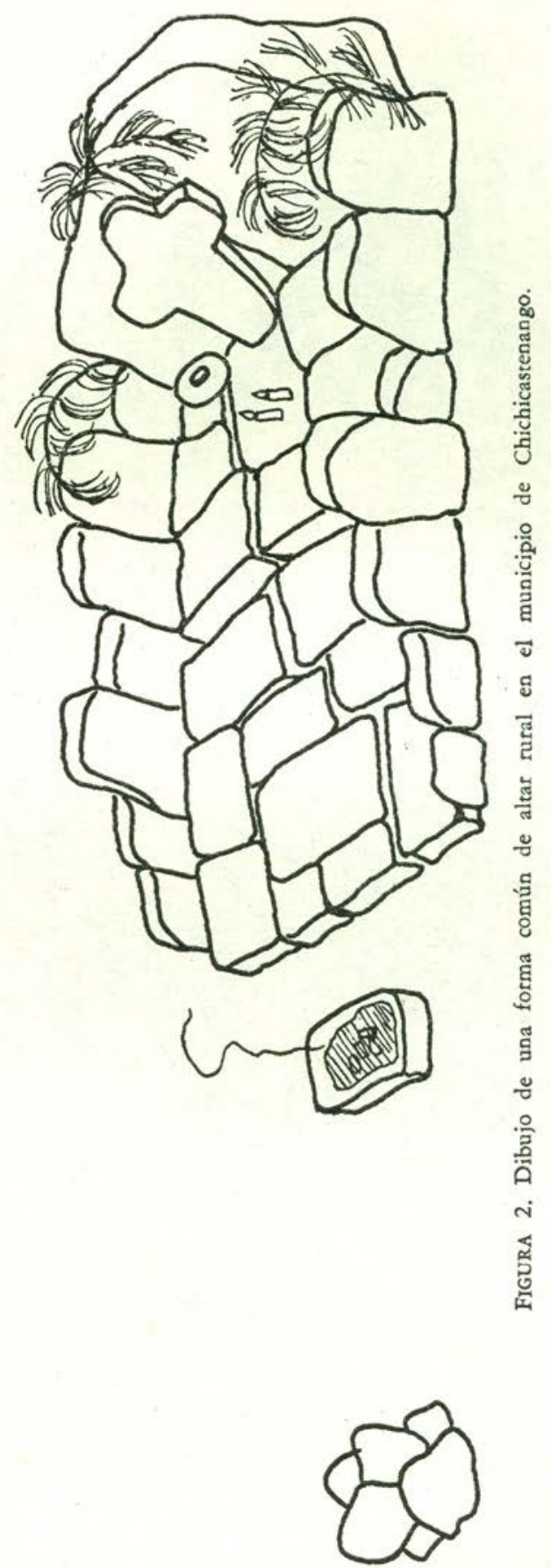